\title{
Ranking State Environmental Outputs: Evidence from Panel Data
}

\author{
JOHN A. LIST AND W. WARREN MCHONE
}

\begin{abstract}
This paper uses state-level pollution data from 1986-1997 to construct two indices that rank U.S. states according to environmental outputs. A major finding is that marginal performers in other indices, such as Wyoming, garner top spots in these ranking systems. The paper also presents findings from fixed and random effects models of panel data that imply state income levels are positively associated with environmental outputs after a threshold level of income is obtained.
\end{abstract}

\section{Introduction}

D ollution is a significant drain on the health, economy, and environment of the global community. In response to these deleterious effects, since the first Earth Day in 1970 the U.S. has allocated more than \$1 trillion to prevent or reduce environmental damages created by industrial and commercial activities (Jaffe et al. 1994). To aid in the regulatory process, many state governments have progressively enhanced their institutional capabilities to monitor polluters more effectively. Indeed, since the Reagan administration's policy of new federalism reversed more than a decade of increased federal prominence in protecting environmental quality, many states have taken primary enforcement responsibilities, leading to a significant variation in pollution control programs across states (Nathan and Doolittle 1983; Lester 1994; Vig and Kraft 1994).

There have been numerous attempts to rank what states have done in terms of environmental protection. ${ }^{1}$ Non-fiscal studies, such as Ridley's (1987) FREE (Fund for Renewable Energy and the Environment) index, report an assessment of where 'states stand' on key environmental topics such as soil conservation, air pollution reduction, hazardous waste management, and renewable energy and

John A. List is an assistant professor, and W. Warren McHone is a professor in economics at the University of Central Florida, Orlando. They thank Ralph d'Arge, Shelby Gerking, Tom Crocker, and Jason Shogren for helpful comments on an earlier draft of this paper. Three reviewers and the editor provided invaluable comments.

Submitted Apr. 1998, revised Apr., Sept. 1999.

(C) 2000 Gatton College of Business and Economics, University of Kentucky. Published by Blackwell Publishers, 350 Main Street, Malden MA 02148 US, and 108 Cowley Road, Oxford, OX4 1JF, UK. 
conservation. Points are then awarded to a state if it has laws that address each of these issues. Other studies, such as Brown and Garner (1988) and Brown et al. (1990), rank states by total environmental expenditures as well as by per capita environmental expenditures. A third set of indices combine fiscal and non-fiscal data to measure a state's commitment to environmental protection. For example, Duerksen (1983) combines state expenditures for pollution control with non-fiscal indicators, such as existence of environmental laws, to produce his environmental index.

Although these studies provide important information regarding states' pollution control efforts, it is a matter of conjecture whether state inputs induce greater environmental outputs. Environmental inputs and outputs may not coincide for a variety of reasons. For example, California may spend fewer dollars per capita to regulate polluters, when compared to other smaller states; nonetheless, California's regulatory department may still have a greater influence due to regulatory scale economies. In this respect, an input ranking may suggest that California is a lax state, whereas a ranking based on output measures may imply the opposite. Many other aspects of the regulatory regime, such as efficiency and firm-level agglomeration economies, may also cause input and output rankings to diverge.

The primary purpose of this paper is to develop a ranking of states on the basis of environmental outputs across both air and water media for the period 1986-1997, and to compare these rankings with the input rankings developed in previous works. The unconditional measure of states' environmental output is then refined by developing a conditional ranking system that controls for income levels across states. Since good economic decisions depend on well-informed agents, these types of indices can provide many useful insights. For example, given that devolution of important regulatory tasks such as environmental protection is at the forefront of public policy debates, it is important to recognize which states have the capability and commitment to carry out pollution control policies. In this case, the conditional rankings provide an indication of those states that are committed to environmental protection, regardless of income levels. Such information could be especially important in understanding the link between economic expansion or contraction and environmental quality.

The balance of the paper is organized as follows. The second section describes the data, and constructs the unconditional index using state-level pollution data. The third section presents the unconditional output rankings for the air and water (lakes and rivers) media, and compares these rankings to each other and to the input rankings of previous studies. A major finding in the unconditional index, explored more fully in the third section, is that marginal performers in other indices, such as Wyoming and South Carolina, garner top spots in this ranking system. The fourth section presents empirical evidence, 
from models of panel data, that supports recent findings in cross-country studies: after a critical level of income is reached, per capita income and environmental quality are positively related. This is the familiar environmental Kuznets curve and suggests that states are not just passive actors in the environmental arena, responding to the dictates of the federal government. In the fifth section, the conditional ranking system is constructed by extracting a component of the residual from the panel data model of the fourth section. Results from the conditional index suggest that controlling for income levels across states is important, as a number of states have quite different rankings when income levels are considered. The last section provides concluding comments.

\section{Data for Ranking State Environmental Outputs}

To provide an indication of states' environmental outputs, panel data on three measures of environmental quality across two media - air and water-are used. The first measure looks at annual data on the percentage of ozone monitors, by state, that had at least one reading that exceeded Federal National Air Quality Standards over the period 1993-97. ' Based on the EPA's 1979 ozone standard an 'exceedance' is defined as the occurrence of a monitor reading of $0.12 \mathrm{ppm}$ (parts per million) for a 1-hour period. For three reasons the focus is on concentrations of ozone. First, ozone has attracted the most regulatory attention due to the limited progress that has been made to reduce concentration levels. Second, since ozone is formed by sunlight-initiated reactions of nitrogen oxides and combinations of other pollutant types, it is primarily local and therefore any confounding effects due to spillovers is avoided. Third, ozone places severe costs on society; adverse health effects associated with ozone exposure include effects on breathing, respiratory illness and symptoms, alterations in the lungs' defenses, aggravation of existing respiratory and cardiovascular disease, and mortality.

The second and third environmental measures are biennial state-level data from 1986-1994 on impaired miles of rivers and impaired acres of lakes. These data come from the National Water Quality Inventory, Report to the Congress, 1986-1994, published by the U.S. Environmental Protection Agency. Data were compiled by professional surveys of rivers and lakes within states. A river or lake is labeled 'impaired' if pollutants such as metals, oxygen-depleting substances, or bacteria render it partially supporting or not supporting designated uses; designated uses include swimming, support of aquatic life, and drinking water supply. Ideally, each state would have submitted a report on the amount of water resources surveyed and impaired every other year; however, due to incomplete reporting, reporting unusable information, poor management, etc., biennial data from 1986-1994 are not available for every state. Nevertheless, at least two years of data are available for each state. Impaired river (lake) miles 
(acres) are divided by total miles (acres) surveyed to account for interstate heterogeneity in river (lake) area.

Table 1 contains descriptive statistics for all three output measures. Given that intrastate variation of ozone exceedances is minute for most states over the period 1993-1997, data indicate a significant amount of variation exists in interstate exceedance levels. For example, the percentage of monitors with ozone exceedances was approximately 20 percent, with a standard deviation of 24.1 percent from 1993-1997. In addition, it is noteworthy that 42 percent of surveyed river miles and 35 percent of surveyed lake miles were labeled impaired from 1986-1994. Table 1 also contains data on per capita income levels across states from 1993-1997, and biennially from 1986-1994, which will be used for the regression analysis in the fourth section.

\section{An Unconditional Ranking of State Environmental Outputs}

Table 2 contains output rankings across the three types of environmental indicators, mean rankings for the two media, and an overall output ranking. The media and overall ranks are calculated using the unweighted rank average from the appropriate columns in Table 2. For example, if state h's rank is 2 for percentage of rivers impaired and 8 for percentage of lakes impaired, the unweighted rank average for state $\mathrm{h}$ is 5 for overall water quality. States are then re-ranked $(1,2, \ldots, 48)$ according to this unweighted average. ${ }^{3}$

TABle 1. Descriptive Statistics ${ }^{A}$

\begin{tabular}{lcccc}
\hline Variable & Mean & Std. Deviation & Minimum & Maximum \\
\hline $\begin{array}{l}\text { Percent of Air Monitors } \\
\text { in Exceedance }\end{array}$ & 20.1 & 24.1 & 0.00 & 100.00 \\
$\begin{array}{l}\text { Percent of Rivers Impaired } \\
\text { Percent of Lakes Impaired }\end{array}$ & 42.0 & 26.0 & 1.00 & 100.00 \\
$\begin{array}{l}\text { Per Capita Income } \\
\text { (Biennial 1986-1994) }\end{array}$ & $\$ 15,280$ & $\$ 2,406$ & $\$ 10,258$ & $\$ 22,462$ \\
$\begin{array}{l}\text { Per Capita Income } \\
\text { (Annual 1993-1997) }\end{array}$ & $\$ 20,496$ & $\$ 3,157$ & $\$ 14,335$ & $\$ 32,177$ \\
\hline
\end{tabular}

A Data for air monitors use annual ozone concentrations (1993-1997); data for rivers and lakes are biennial from 1986-1994; data for income are biennial (1986-1994) in 1987 dollars and annual (1993-1997) in 1992 dollars. 
TABLE 2. UnConditional State EnVIRONMENTAL OUtPUt RANKINGS ${ }^{A}$

\begin{tabular}{|c|c|c|c|c|c|c|}
\hline State & $\begin{array}{c}\text { Ozone \% } \\
\text { Exceedances }\end{array}$ & $\begin{array}{l}\text { Air } \\
\text { Rank } \\
\end{array}$ & $\begin{array}{c}\text { Rivers } \\
\% \text { Impaired } \\
\end{array}$ & $\begin{array}{l}\text { Lakes } \\
\% \text { Impaired }\end{array}$ & $\begin{array}{l}\text { Water } \\
\text { Rank } \\
\end{array}$ & $\begin{array}{c}\text { Overall } \\
\text { Rank }\end{array}$ \\
\hline Alabama & 18.6 & 28 & 21.6 & 21.9 & 13 & 18 \\
\hline Arizona & 13.9 & 22 & 67.7 & 64.7 & 42 & 37 \\
\hline Arkansas & 7.3 & 16 & 55.5 & 57.6 & 35 & 26 \\
\hline California & 38.5 & 41 & 63.3 & 72.5 & 45 & 46 \\
\hline Colorado & 4.9 & 12 & 11.1 & 9.3 & 2 & 3 \\
\hline Connecticut & 86.0 & 47 & 33.8 & 20.6 & 18 & 38 \\
\hline Delaware & 52.0 & 42 & 66.5 & 64.2 & 40 & 46 \\
\hline Florida & 7.4 & 17 & 33.7 & 59.8 & 30 & 23 \\
\hline Georgia & 36.1 & 40 & 29.2 & 15.5 & 15 & 33 \\
\hline Idaho & 0.0 & 1 & 17.3 & 21.6 & 11 & 1 \\
\hline Illinois & 17.9 & 27 & 52.8 & 86.0 & 47 & 42 \\
\hline Indiana & 23.1 & 31 & 28.4 & 0.17 & 4 & 12 \\
\hline lowa & 0.0 & 1 & 89.7 & 45.3 & 44 & 21 \\
\hline Kansas & 8.3 & 18 & 71.0 & 76.3 & 48 & 39 \\
\hline Kentucky & 14.4 & 23 & 32.4 & 11.3 & 14 & 13 \\
\hline Louisiana & 29.6 & 38 & 42.6 & 32.0 & 24 & 36 \\
\hline Maine & 27.7 & 34 & 1.9 & 21.7 & 3 & 13 \\
\hline Maryland & 71.6 & 46 & 12.3 & 17.5 & 7 & 30 \\
\hline Mass. & 27.1 & 36 & 61.6 & 61.3 & 39 & 43 \\
\hline Michigan & 28.9 & 37 & 4.5 & 8.4 & 1 & 16 \\
\hline Minnesota & 0.0 & 1 & 67.2 & 30.8 & 32 & 11 \\
\hline Mississippi & 3.3 & 10 & 49.0 & 19.4 & 22 & 10 \\
\hline Missouri & 33.5 & 39 & 47.7 & 3.8 & 16 & 33 \\
\hline Montana & 0.0 & 1 & 40.2 & 52.1 & 28 & 8 \\
\hline N. Carolina & 11.7 & 20 & 31.0 & 5.0 & 9 & 8 \\
\hline N. Dakota & 0.0 & 1 & 25.7 & 45.2 & 23 & 5 \\
\hline Nebraska & 0.0 & 1 & 58.2 & 57.8 & 36 & 13 \\
\hline Nevada & 0.0 & 1 & 69.8 & 48.2 & 38 & 17 \\
\hline New Hampshire & 12.2 & 21 & 19.1 & 9.8 & 5 & 6 \\
\hline New Jersey & 56.5 & 43 & 71.1 & 28.0 & 33 & 45 \\
\hline New Mexico & 4.8 & 11 & 66.7 & 64.8 & 41 & 29 \\
\hline New York & 24.6 & 33 & 13.5 & 47.5 & 20 & 30 \\
\hline Ohio & 17.6 & 26 & 47.2 & 85.6 & 43 & 41 \\
\hline Oklahoma & 21.1 & 29 & 65.8 & 72.8 & 46 & 43 \\
\hline Oregon & 11.4 & 19 & 48.1 & 28.9 & 26 & 21 \\
\hline Penn. & 21.9 & 30 & 26.1 & 39.5 & 21 & 26 \\
\hline Rhode Island & 56.7 & 45 & 19.4 & 14.8 & 8 & 30 \\
\hline S. Carolina & 4.9 & 13 & 25.6 & 12.4 & 10 & 4 \\
\hline S. Dakota ${ }^{b}$ & NA & NA & 70.9 & 17.7 & 27 & NA \\
\hline Tennessee & 14.5 & 24 & 35.4 & 19.4 & 19 & 19 \\
\hline Texas & 56.6 & 44 & 20.6 & 8.4 & 6 & 25 \\
\hline Utah & 7.3 & 15 & 54.4 & 38.3 & 29 & 20 \\
\hline Vermont & 0.0 & 1 & 18.5 & 21.0 & 12 & 2 \\
\hline Virginia & 24.1 & 32 & 42.9 & 9.5 & 17 & 24 \\
\hline W. Virginia & 15.8 & 25 & 66.4 & 40.4 & 34 & 35 \\
\hline Washington & 5.0 & 14 & 65.9 & 50.6 & 37 & 26 \\
\hline Wisconsin & 27.7 & 35 & 24.7 & 71.6 & 31 & 39 \\
\hline Wyoming & 0.0 & 1 & 36.1 & 40.2 & 25 & 6 \\
\hline
\end{tabular}

${ }^{a}$ Overall media and output rankings are calculated using the unweighted rank average from the appropriate columns.

${ }^{\mathrm{b}} \mathrm{S}$. Dakota did not have any Ozone monitors during the study period. 
Column 1 in Table 2 contains an overall ranking for the medium air. States with traditionally small industrial bases and low population densities, such as Wyoming and North Dakota, tend to have a high output ranking (low exceedance level), while states with acute air quality problems, such as New Jersey and California, perform poorly. Although other indices have given New Jersey and California high marks due to their regulatory inputs, their outputs are found to remain below average. Some states, however, are seemingly getting a free lunch-states such as Wyoming and North Dakota, which, according to Ridley's FREE index, are not committed to substantial air quality regulation, have ozone exceedances well below the average state. This result makes intuitive sense since there is little incentive for states with low polluting potential to have numerous environmental codes and regulations.

Column 5 in Table 2 presents an overall water quality ranking. These water rankings indicate that states with traditionally strong water programs, such as Colorado and Michigan, also have above average water quality. A surprising finding in column 5 is the relatively low rankings of states such as Iowa, Minnesota, Nebraska, and Nevada. Given that these states are leaders in the air quality category, one would assume that they would also have better than average water quality rankings, which is not the case. This trend is reversed for states such as Indiana, Maine, Maryland, and Michigan, which have above average marks in the water quality rankings while performing marginally in the air rankings.

Column 6 in Table 2 contains an overall environmental output ranking. The rankings indicate that Idaho, Colorado, Vermont, and South Carolina are near the top, while Delaware, California, New Jersey, Massachusetts, and Oklahoma are near the bottom. Comparing the output rankings of this study with the fiscal and non-fiscal commitment rankings of previous studies suggests that there is not a direct correlation between inputs (broadly defined) and outputs. Table 3 presents the rank correlation coefficients between these air and water rankings and the total (input oriented) rankings from studies due to Duerksen (1983), Ridley (1987), and Brown and Garner (1988). DTR, RTR, BGR, denote indices due to Duerksen, Ridley, and Brown and Garner, respectively. UAR, UWR, and UOR represent this study's unconditional air, water, and overall ranking. Referring to the first two rows in Table 3, it can be seen that all three output rankings are negatively related to the input oriented rankings of both Duerksen and Ridley. These input rankings are both based on a variety of fiscal and nonfiscal data which are intended to reflect "State Commitment to Environmental Protection." This finding is important in that it suggests that "commitment to environmental protection" and the variety of tangible and intangible inputs that are represented by these rankings do not necessarily translate into relatively higher environmental outputs. This result may be due to many phenomena, 
Table 3. Correlation of Output Rankings and Rankings from Previous STUDIES

\begin{tabular}{lccrrrr}
\hline & DTR $^{\mathrm{a}}$ & $\mathrm{RTR}^{\mathrm{b}}$ & $\mathrm{BGR}^{\mathrm{c}}$ & UAR $^{\mathrm{d}}$ & UWR $^{\mathrm{e}}$ & UOR $^{\mathrm{f}}$ \\
\hline DTR & \multirow{2}{*}{1.000} & 0.681 & -0.013 & -0.222 & -0.029 & -0.174 \\
RTR & & 1.000 & -0.187 & -0.412 & -0.048 & -0.343 \\
BGR & & & 1.000 & 0.254 & 0.001 & 0.228 \\
UAR & & & 1.000 & -0.193 & 0.668 \\
UWR & & & & 1.000 & 0.584 \\
UOR & & & & & 1.000 \\
\hline
\end{tabular}

a Total ranking based on "States Commitment to Environmental Protection" from Duerksen (1983).

b Total ranking based on "States Commitment to Environmental Protection" from Ridley (1987).

${ }^{c}$ Ranking of states based on " percent State Environmental Expenditures of Total State Expenditures" from Brown and Garner (1988).

${ }^{d}$ Unconditional state environmental output ranking based on ozone exceedances from Table 2.

${ }^{\mathrm{e}}$ Unconditional state environmental output ranking based on combined rivers and lakes impairment from Table 2.

' Unconditional overall state output ranking based on combined air and water rankings from Table 2.

including scale economies in regulation or abatement, size/makeup of manufacturers, agglomerations, and assimilative capacities of local environments. In addition, this finding may reflect the fact that the existence of "environmental friendly" state laws and voting records are not sufficient to insure higher levels of environmental outputs.

Concerning the more direct fiscal measure of state spending on environmental inputs that is provided by Brown and Garner's (1988) ranking, a positive correlation is found between this study's air and overall rankings and their ranking (row 3 of Table 3). This result is encouraging in that it suggests that the direct commitment of state funds to environmental protection can lead to a relatively higher level of environmental outputs.

Another interesting premise associated with the output rankings in Table 2 is the amount of correlation across media types. Referring to the fourth row in Table 3, it can be seen that this air ranking is negatively correlated with the water ranking. This may suggest that any additional pressure put on heavy air (water) polluters to clean up may occur at the expense of less attention paid to water (air) pollution problems. This substitution effect could explain why some states are leaders in the air component whereas they garner marginal ranks in the water resources area. 


\section{Determinants of State Rankings}

To explore the determinants of state environmental outputs, further information is extrapolated from the panel data set by using state-level annual ozone exceedances data (1993-1997) and biennial water quality data (19861994), as the endogenous variable in a regression framework. Because many factors that affect a state's environmental policies, such as state partisanship, institutional capacity, and community characteristics, are in part determined by state per capita income, the empirical wealth model of Grossman and Krueger (1995) and Holtz-Eakin and Selden (1995) is estimated: ${ }^{4}$

$$
\mathrm{E}_{\mathrm{it}}=\alpha_{\mathrm{i}}+\beta_{1} \mathrm{Y}_{\mathrm{it}}+\beta_{2} \mathrm{Y}_{\mathrm{it}}^{2}+\varphi_{\mathrm{t}}+\varepsilon_{\mathrm{it}}
$$

where $E_{i t}$ is the environmental indicator, $\alpha_{i}$ represent state fixed/random effects, $\mathrm{Y}_{\mathrm{it}}$ denotes per capita income, $\varphi_{\mathrm{t}}$ represent time fixed/random effects, $\varepsilon_{\mathrm{it}}$ is the contemporaneous disturbance term, and subscripts $i$ and $t$ indicate state and time period. $^{5} \quad$ As previously mentioned, equation (1) makes the environmental indicator a function of only per capita income and state and time dummies. ${ }^{6}$ Possible explanatory variables that may be endogenously related to income growth have been excluded in order to focus more directly on total effects of $Y$ on $\mathrm{E}$, rather than on partial effects holding certain determinants of $\mathrm{Y}$ constant. Examples of determinants of income growth might include the level of education, composition of output, and regulatory policy.

Econometric estimates of equation (1) are obtained for both fixed (FE) and random (RE) effects models of panel data. Both estimation approaches control for unmeasured heterogeneity that pooled ordinary least squares ignores. Random effects estimates of equation (1) yield coefficients that are not conditioned on unmeasured state effects, whereas fixed effects yield coefficients that are conditioned on the unmeasured characteristics. Hence, fixed effects estimates are inefficient since they consider only the within-state variation of the environmental indicator and ignore any between-state variation. Yet, if the state or time effects are correlated with income levels, random effects estimates are biased and inconsistent while the within estimator remains unbiased and consistent. In consequence, Hausman (1978) tests of orthogonality are considered when comparing estimates from fixed and random effects models.

Results from the estimated panel models are presented in Table 4. A first issue regards the potential heterogeneity bias associated with pooled ordinary least squares. F-tests from the fixed effects models, $F\left(\alpha_{i}=0\right)$ and $F\left(\varphi_{t}=0\right)$, imply that the homogeneous null is rejected at the 1 percent significance level for all models except the rivers model $\mathrm{F}\left(\varphi_{\mathrm{t}}=0\right)=0.99$. Furthermore, the Lagrange Multiplier test $\left(\sim \chi^{2}\right)$ in the random effects model, which is the counterpart to the F-test for homogeneity in the fixed effects models, suggests that the null hypothesis of homogeneity of unmeasured state- and time-specific 
Table 4. Panel Data Estimates for Environmental Output Equation

\begin{tabular}{|c|c|c|c|c|c|c|}
\hline \multirow{2}{*}{$\begin{array}{l}\text { Independent } \\
\text { Variable }\end{array}$} & \multicolumn{2}{|c|}{ Ozone } & \multicolumn{2}{|c|}{ Rivers } & \multicolumn{2}{|c|}{ Lakes } \\
\hline & FE & RE & $\mathrm{FE}$ & RE & FE & $\mathrm{RE}$ \\
\hline Constant & - & $\begin{array}{c}-0.91 \\
(-1.62)\end{array}$ & - & $\begin{array}{l}-383.8 \\
(-1.6)\end{array}$ & - & $\begin{array}{c}-825.4^{*} \\
(-2.1)\end{array}$ \\
\hline Income & $\begin{array}{l}0.23 \mathrm{E}-3^{*} \\
(2.3)\end{array}$ & $\begin{array}{c}0.72 \mathrm{E}-4 \\
(1.43)\end{array}$ & $\begin{array}{c}156.60^{*} \\
(2.1)\end{array}$ & $\begin{array}{c}79.22 \\
(1.5)\end{array}$ & $\begin{array}{c}121.25 \\
(1.0)\end{array}$ & $\begin{array}{c}167.67^{*} \\
(2.0)\end{array}$ \\
\hline Income ${ }^{2}$ & $\begin{array}{c}-0.41 \mathrm{E}-8^{*} \\
(-2.4)\end{array}$ & $\begin{array}{c}-0.9 \mathrm{E}-9^{*} \\
(-0.76)\end{array}$ & $\begin{array}{l}-8.19^{\star} \\
(-2.1)\end{array}$ & $\begin{array}{l}-4.10 \\
(-1.5)\end{array}$ & $\begin{array}{l}-5.97 \\
(-0.9)\end{array}$ & $\begin{array}{l}-8.53^{*} \\
(-1.99)\end{array}$ \\
\hline $\begin{array}{l}F\left(\alpha_{i}=0\right) \\
(D F)\end{array}$ & $\begin{array}{c}7.94^{*} \\
(45,186)\end{array}$ & - & $\begin{array}{c}7.96^{*} \\
(47,159)\end{array}$ & - & $\begin{array}{c}7.17^{\star} \\
(47,122)\end{array}$ & - \\
\hline $\begin{array}{l}F\left(\varphi_{t}=0\right) \\
(D F)\end{array}$ & $\begin{array}{c}7.41^{*} \\
(4,181)\end{array}$ & - & $\begin{array}{c}0.99 \\
(4,154)\end{array}$ & - & $\begin{array}{c}3.39^{*} \\
(4,117)\end{array}$ & - \\
\hline $\begin{array}{l}\text { LM } \\
\text { (DF) }\end{array}$ & - & $\begin{array}{c}112^{*} \\
(2)\end{array}$ & - & $\begin{array}{c}107^{*} \\
(2)\end{array}$ & - & $\begin{array}{l}85^{*} \\
(2)\end{array}$ \\
\hline $\begin{array}{l}\text { Hausman } \\
\text { (DF) }\end{array}$ & $\begin{array}{l}11.1^{*} \\
(2)\end{array}$ & - & $\begin{array}{l}1.99 \\
(2)\end{array}$ & - & $\begin{array}{c}0.63 \\
(2)\end{array}$ & - \\
\hline $\mathrm{R}^{2}$ & 0.75 & - & 0.72 & - & 0.78 & - \\
\hline Adj. $R^{2}$ & 0.67 & - & 0.62 & - & 0.68 & - \\
\hline $\begin{array}{l}\text { Turning } \\
\text { Point (1987\$) }\end{array}$ & - & - & $\$ 14,044$ & $\$ 15,722$ & $\$ 25,336$ & $\$ 18,398$ \\
\hline $\begin{array}{l}\text { Turning } \\
\text { Point (1992\$) }\end{array}$ & $\$ 28,048$ & $\$ 42,261$ & - & - & - & - \\
\hline $\begin{array}{l}\text { Elasticity } \\
\text { (overall mean) }\end{array}$ & 6.35 & 3.60 & -1.21 & 0.22 & 6.22 & 3.31 \\
\hline $\begin{array}{l}\text { Elasticity } \\
\text { (sample range } \\
\text { of incomes) }\end{array}$ & $\begin{array}{l}8.06 \\
-5.44\end{array}$ & $\begin{array}{l}3.31 \\
2.26\end{array}$ & $\begin{array}{l}5.32 \\
-7.52\end{array}$ & $\begin{array}{c}3.49 \\
-2.94\end{array}$ & $\begin{array}{l}10.9 \\
1.62\end{array}$ & $\begin{array}{c}10.1 \\
-3.26\end{array}$ \\
\hline $\mathrm{N}$ & 235 & 235 & 209 & 209 & 172 & 172 \\
\hline
\end{tabular}

${ }^{a}$ Dependent variable for air regressions is percentage of air monitors in exceedance of Federal air quality guidelines in state $\mathrm{i}$; dependent variable for water regressions is percentage of lakes or rivers labeled impaired in state $\mathrm{i}$. Both water regressions are in log-log form; air regressions are in linear form.

${ }^{b} t$-statistics are in parentheses beneath coefficient estimates.

* significant at .05 level.

effects is rejected at the 1 percent level. Therefore, time and state effects are included in all estimated regression models. ${ }^{7}$ Another issue regards which of the models - fixed or random effects - should be used for inference. The Hausman statistics $\left(\sim \chi^{2}\right)$ suggest that the orthogonality assumption is violated in the ozone 
exceedances regression, but that the effects and income levels are uncorrelated in both water quality regressions. This finding implies that the fixed effects estimates are appropriate in the ozone model, whereas the more efficient generalized least squares (GLS) estimates are preferred in the water quality regressions. Finally, this wealth model appears sufficiently rich to capture the variation in the regressand as witnessed by the explanatory power for each regression, which ranges from $0.72-0.78$.

Coefficient estimates of the income terms for both fixed and random effects models, which are jointly significant at the $\mathrm{p}<.05$ confidence level for all models, suggest indicators of environmental quality respond positively to income changes after a certain level of income is achieved. For example, estimates from the fixed effects model for ozone suggest that the percentage of ozone monitors exceeding federal standards is positively correlated with increases in income levels until a threshold level of income is reached $(\$ 28,048$ in 1992 dollars); thereafter, the percentage of monitors exceeding federal guidelines decreases with increases in income. This finding is similar to other cross-country findings that test for an inverted-U shape relationship (Kuznets curve) between air quality and income levels (Grossman and Krueger 1995; Holtz-Eakin and Selden 1995; List and Gallet 1999), and implies that the environmental output rankings for ozone exceedances are positively associated with constituent income levels after a threshold level of income is obtained. But it should be noted that since few states achieved an income level greater than $\$ 28,048$ by 1997 , this finding of an inverted-U relationship between air quality and income is out of sample for many states. Estimated turning points for the water indicators in the random effects models range from $\$ 15,722-18,398$ in 1987 dollars, implying that most states are currently on the rightward portion of the estimated environmental Kuznets curve (EKC). These results indicate that polluting firms may be responding to local pressures for improved environmental quality. This pressure could operate through several channels, including activities of environmental public interest groups, community groups, or state regulators.

Table 4 also contains estimates of income elasticities. By nature, elasticity estimates range from large positive values (left-most point on the EKC) to large (absolute terms) negative values (right-most point of the EKC). Therefore elasticity estimates are presented at the overall sample mean ( $\$ 20,496$ (ozone) and $\$ 15,280$ (water regressions)), and across the range of incomes in the sample (ozone $=\$ 14,335-\$ 32,177$; water regressions $=\$ 10,258-\$ 22,462)$. Elasticity estimates from the ozone fixed-effects model in column 1 suggest that the percentage of ozone exceedances has been quite sensitive to income levels as the range of elasticities is 8.06 to -5.44 . Measured at the overall sample mean, it is 
found that ozone exceedances are quite sensitive to income changes as the elasticity is 6.35 .

Columns 3-6 in Table 4 contain income elasticity estimates for rivers and lakes. Results from the within estimator for the river regression indicate that river quality is a superior good, since the mean elasticity estimate is -1.21 . This result indicates that for a given state, water quality is highly responsive to income growth. However, the GLS elasticity estimate of 0.22 suggests river quality is not acutely sensitive to income changes at the overall sample mean. Since the random effects estimates make use of state-to-state variation in income, this result indicates that moving from a low income state to a higher income state does not lead to proportionately greater environmental outputs. Although a matter of conjecture, this finding may imply that states' river management programs are converging. ${ }^{8}$ Finally, elasticity estimates for the lake regression, which indicate that most states are on the left-hand portion of the EKC, imply that lake quality is extremely sensitive to income changes, since mean elasticities in the RE model range from -3.26 to 10.9 .

In sum, elasticity estimates imply that air quality is at least a normal good whereas water quality, especially lake quality, is highly sensitive to income changes. Given the current increase in state per capita income levels, these results suggest that if interstate pollution spillovers are not too important, then over time, state governments still could end up with equally if not more stringent environmental standards than those imposed at the federal level. Additionally, and in contrast to predictions made by those responsible for framing U.S. environmental policy in the late 1960s, they even may suggest an expanded future role for state governments in providing environmental protection, particularly in light of Tiebout's (1956) analysis of consumers who "vote with their feet" for their preferred basket of public services.

\section{A Conditional Ranking System}

Although a ranking system that measures states' environmental outputs was previously constructed, it should be considered unconditional since no effort was made to control for important time-varying factors that can induce higher or lower output rankings. If the shifting of environmental responsibilities to state and local governments continues, it is important to understand which states will be able to meet the challenges of pollution control even if their economies begin to slow down. Hence, the information from the regression model in equation (1) is used to construct a conditional ranking system. This index can shed light on the willingness of states to assume an important regulatory role in the environmental arena even in times of recession. Many critics would argue that faced with worsening fiscal constraints, some states will drop many of their programs altogether (Lester 1986). This conditional index should help to specify 
the states that may not have the willingness to absorb the increased regulatory tasks inherent in a federalist system.

To construct the index, the fixed effects component, $\alpha_{i}$, of the residuals is examined in equation (1). The fixed effects capture any time-invariant factors that affect the environmental measure, $\mathrm{E}_{\mathrm{it}}$. Given the short length of this sample period, regulatory factors potentially included in this vector are states' attitudes toward environmental protection, institutional particulars of pollution control, and commitment to a clean environment. Note that the estimated fixed effects are calculated conditioned on income levels, hence they provide a measure of a state's commitment to pollution control independent of state income levels. In this regard, the new ranking system should be considered conditional since an important component of pollution levels is controlled in the regression equation. Since the fixed effects are parametric shifts of the regression equation, higher values imply lower environmental outputs.

Table 5 contains this conditional ranking system for each of the three environmental measures. Considering the air rankings in Column 2, it can be seen that states with top rankings in the conditional index are much different from those with top rankings in the unconditional index of Table 2. For example, Table 5 suggests that holding income constant across states, New Jersey will tend to have the least percentage of ozone monitors in exceedance of federal air quality guidelines. This is much different from the unconditional ranking in Table 2, where New Jersey was ranked 43rd. Although there are some other states that significantly change across the unconditional and conditional indices, a rank correlation coefficient between rankings suggests that the two types of indices are highly correlated (air: 0.53 ; water: 0.84 ; overall: 0.55 ). This result suggests that both income and other factors such as preferences and statewide beliefs are important determinants of environmental outcomes.

Table 6 provides an individual comparison of the shift in state rankings between the unconditional and conditional indices. The entries in Table 6 represent the decrease or increase in rank for each state when the corresponding environmental output index is calculated while controlling for income. Focusing on the overall ranking, it can be seen that, holding income constant, Mississippi, Montana, Utah, Kentucky, Alabama, and New Mexico all experience a substantial decrease in their rankings. On the other end of the spectrum, Georgia, Virginia, Illinois, and New Jersey enjoy a substantial improvement in their overall environmental ranking after taking account of income. It is interesting to note that with the exception of Mississippi, Utah, and Georgia, the primary determinant that causes states to shift relative ranks when moving from the unconditional to the conditional index is changes in the air quality ranking. This result suggests that income levels are an important force in determining relative air quality rankings. 
TABLE 5 CONDITIONAL STATE ENVIRONMENTAL OUTPUT RANKINGS ${ }^{A}$

\begin{tabular}{|c|c|c|c|c|c|c|}
\hline State & $\begin{array}{l}\text { Ozone } \\
\text { Fixed Effect }\end{array}$ & $\begin{array}{l}\text { Air } \\
\text { Rank }\end{array}$ & $\begin{array}{l}\text { Rivers } \\
\text { Fixed Effect }\end{array}$ & $\begin{array}{l}\text { Lakes } \\
\text { Fixed Effect }\end{array}$ & $\begin{array}{l}\text { Water } \\
\text { Rank }\end{array}$ & $\begin{array}{l}\text { Overa } \\
\text { Rank }\end{array}$ \\
\hline Alabama & 0.150 & 38 & -0.640 & 0.940 & 20 & 34 \\
\hline Arizona & 0.130 & 34 & 0.560 & 1.270 & 42 & 42 \\
\hline Arkansas & 0.020 & 25 & 0.550 & -0.240 & 21 & 20 \\
\hline California & 0.050 & 29 & 0.820 & 0.400 & 36 & 37 \\
\hline Colorado & -0.280 & 4 & -1.070 & -1.890 & 3 & 1 \\
\hline Connecticut & 0.410 & 47 & 1.440 & -1.960 & 17 & 35 \\
\hline Delaware & 0.130 & 34 & 0.780 & 0.330 & 32 & 38 \\
\hline Florida & -0.210 & 6 & 0.010 & 0.630 & 28 & 13 \\
\hline Georgia & 0.150 & 38 & -1.190 & -0.950 & 7 & 19 \\
\hline Idaho & -0.037 & 20 & -0.590 & -1.770 & 6 & 7 \\
\hline Illinois & -0.200 & 8 & 0.670 & 0.640 & 38 & 20 \\
\hline Indiana & 0.030 & 26 & -0.300 & -4.700 & 1 & 10 \\
\hline lowa & -0.170 & 12 & 0.850 & 0.990 & 43 & 30 \\
\hline Kansas & -0.150 & 14 & 0.530 & 1.030 & 39 & 27 \\
\hline Kentucky & 0.130 & 34 & -0.090 & 0.400 & 21 & 30 \\
\hline Louisiana & 0.290 & 44 & 0.200 & 1.610 & 41 & 46 \\
\hline Maine & -0.160 & 13 & -3.030 & 0.130 & 4 & 4 \\
\hline Maryland & 0.290 & 44 & -0.650 & -1.310 & 9 & 27 \\
\hline Mass. & 0.140 & 37 & 1.240 & -0.130 & 32 & 39 \\
\hline Michigan & -0.010 & 22 & -2.090 & -1.400 & 2 & 6 \\
\hline Minnesota & -0.320 & 3 & 0.750 & -0.430 & 23 & 7 \\
\hline Mississippi & 0.110 & 33 & 0.370 & 1.860 & 45 & 45 \\
\hline Missouri & 0.210 & 41 & 0.266 & -2.390 & 8 & 25 \\
\hline Montana & -0.003 & 24 & 0.010 & 1.670 & 40 & 35 \\
\hline N. Carolina & -0.360 & 2 & -0.200 & -1.190 & 13 & 3 \\
\hline N. Dakota & -0.190 & 9 & -0.310 & 1.450 & 35 & 18 \\
\hline Nebraska & -0.050 & 19 & 0.450 & 0.180 & 27 & 20 \\
\hline Nevada & -0.033 & 21 & 1.060 & -0.130 & 30 & 26 \\
\hline New Hampshire & -0.210 & 6 & -0.890 & -1.700 & 5 & 2 \\
\hline New Jersey & -2.580 & 1 & 1.460 & -0.920 & 25 & 7 \\
\hline New Mexico & 0.100 & 30 & 0.440 & 2.100 & 47 & 44 \\
\hline New York & 0.101 & 32 & -0.430 & -0.390 & 16 & 24 \\
\hline Ohio & -0.070 & 18 & 0.130 & 1.140 & 37 & 30 \\
\hline Oklahoma & 0.200 & 40 & 0.520 & 1.930 & 46 & 47 \\
\hline Oregon & -0.100 & 15 & 0.180 & 0.380 & 26 & 17 \\
\hline $\begin{array}{l}\text { Penn. } \\
\text { Rhode Island }\end{array}$ & $\begin{array}{r}-0.090 \\
0.250\end{array}$ & $\begin{array}{l}16 \\
43\end{array}$ & $\begin{array}{l}-0.270 \\
-0.550\end{array}$ & $\begin{array}{r}0.020 \\
-1020\end{array}$ & 18 & $\begin{array}{l}13 \\
29\end{array}$ \\
\hline S. Carolina & $\begin{array}{r}0.030 \\
\text { NA }\end{array}$ & 26 & $\begin{array}{r}-0.390 \\
0.670\end{array}$ & $\begin{array}{r}-0.730 \\
0.460\end{array}$ & 14 & $\begin{array}{l}16 \\
N A\end{array}$ \\
\hline Tennessee & -0.010 & 22 & -0.057 & 0.490 & 24 & 20 \\
\hline Texas & 0.380 & 46 & -0.780 & -1.100 & 10 & 33 \\
\hline Utah & 0.100 & 30 & 0.390 & 1.680 & 44 & 41 \\
\hline Vermont & -0.090 & 16 & -0.710 & -0.130 & 15 & 12 \\
\hline Virginia & -0.190 & 9 & -0.030 & -1.490 & 12 & 5 \\
\hline W. Virginia & 0.034 & 28 & 0.720 & 1.950 & 48 & 42 \\
\hline Washington & -0.280 & 4 & 0.780 & 0.170 & 31 & 15 \\
\hline Wisconsin & 0.240 & 42 & -0.430 & 1.110 & 29 & 40 \\
\hline Wyoming & -0.180 & 11 & -0.300 & 0.190 & 19 & 11 \\
\hline
\end{tabular}

${ }^{a}$ Overall media and output rankings are calculated using the unweighted rank average from the appropriate columns.

${ }^{b} \mathrm{~S}$. Dakota did not have any Ozone monitors during the study period. 
TABLE 6 CHANGES IN RANK BETWEEN UNCONDITIONAL AND CONDITION RANKINGS

\begin{tabular}{|c|c|c|c|}
\hline State & $\begin{array}{c}\text { Change in } \\
\text { Air rank }\end{array}$ & $\begin{array}{l}\text { Change in } \\
\text { Water rank }\end{array}$ & $\begin{array}{l}\text { Change in } \\
\text { Overall rank }\end{array}$ \\
\hline Mississippi & -23 & -23 & -35 \\
\hline Montana & -23 & -12 & -27 \\
\hline Utah & -15 & -15 & -21 \\
\hline Kentucky & -11 & -7 & -17 \\
\hline Alabama & -10 & -7 & -16 \\
\hline New Mexico & -19 & -6 & -15 \\
\hline N. Dakota & -8 & -12 & -13 \\
\hline S. Carolina & -13 & -4 & -12 \\
\hline Louisiana & -6 & -17 & -10 \\
\hline Vermont & -15 & -3 & -10 \\
\hline lowa & -11 & 1 & -9 \\
\hline Nevada & -20 & 8 & -9 \\
\hline Texas & -2 & -4 & -8 \\
\hline Nebraska & -18 & 9 & -7 \\
\hline W. Virginia & -3 & -14 & -7 \\
\hline Idaho & -19 & 5 & -6 \\
\hline Arizona & -12 & 0 & -5 \\
\hline Wyoming & -10 & 6 & -5 \\
\hline Oklahoma & -11 & 0 & -4 \\
\hline Tennessee & 2 & -5 & -1 \\
\hline Wisconsin & -7 & 2 & -1 \\
\hline Rhode Island & 2 & -3 & 1 \\
\hline Colorado & 8 & -1 & 2 \\
\hline Indiana & 5 & 3 & 2 \\
\hline Connecticut & 0 & 1 & 3 \\
\hline Maryland & 2 & -2 & 3 \\
\hline Mass. & -1 & 7 & 4 \\
\hline Minnesota & -2 & 9 & 4 \\
\hline New Hampshire & 15 & 0 & 4 \\
\hline Oregon & 4 & 0 & 4 \\
\hline N. Carolina & 18 & -4 & 5 \\
\hline Arkansas & -9 & 14 & 6 \\
\hline New York & 1 & 4 & 6 \\
\hline Delaware & 8 & 8 & 8 \\
\hline Missouri & -2 & 8 & 8 \\
\hline California & 12 & 9 & 9 \\
\hline Maine & 21 & -1 & 9 \\
\hline Florida & 11 & 2 & 10 \\
\hline Michigan & 15 & -1 & 10 \\
\hline Ohio & 8 & 6 & 11 \\
\hline $\begin{array}{l}\text { Washington } \\
\text { Kansas }\end{array}$ & $\begin{array}{r}10 \\
4\end{array}$ & $\begin{array}{l}6 \\
9\end{array}$ & $\begin{array}{l}11 \\
12\end{array}$ \\
\hline Penn. & 14 & 3 & 13 \\
\hline Georgia & 2 & 8 & 14 \\
\hline Virginia & 23 & 5 & 19 \\
\hline Illinois & 19 & 9 & 22 \\
\hline $\begin{array}{l}\text { New Jersey } \\
\text { S. Dakota }\end{array}$ & $\begin{array}{r}42 \\
\text { NA }\end{array}$ & $\begin{array}{r}8 \\
-7\end{array}$ & $\begin{array}{r}38 \\
\text { NA }\end{array}$ \\
\hline
\end{tabular}

a Entries represent difference between unconditional ranking in Table 2 and the corresponding conditional ranking in Table 5. 


\section{Concluding Remarks}

Researchers have developed several indices that rank states' efforts to protect their environments. The ranking system in this study highlights outputs rather than inputs and uses state-level panel data on three indicators of environmental quality across two media types: air and water. This approach is novel in the area of environmental indices and provides interesting insights into comparative state analyses. Results indicate that input and output rankings can lead to quite disparate measures, as traditional laggards in input indices, such as Wyoming and South Carolina, are leaders in provisioning of environmental goods. Yet, ranking across media in these output indices appears to be inversely related. This substitution effect may imply that any additional pressure put on heavy air (water) polluters to clean up may occur at the expense of less attention paid to water (air) pollution problems.

Parameter estimates from models of panel data indicate that income levels are positively associated with the rankings after a threshold level of income is obtained. Additionally, estimates suggest that air quality is a normal, if not superior, good, and water quality, especially lake quality, is highly sensitive to income changes. These results may suggest that if interstate pollution spillovers are not too important, then over time, state governments still could end up with equally if not more stringent environmental standards than those imposed at the federal level.

Finally, a few qualifiers are in order. First, the indices should not be taken as an absolute assessment of the quality of any state's environment. Given the numerous other variables that affect a state's environmental quality, including other air and water pollutants, ecosystem resilience, groundwater contamination, endangered species protection, hazardous waste, toxic runoff, solid waste, etc., these measures merely provide a first brush at quantifying the multi-dimensional aspects of a state's environmental quality. Second, if other environmental indicators are used to measure environmental quality, a much different relative ranking of interstate environmental programs may be produced. Nevertheless, the index could provide a rough measure of future environmental stringency across states. This could prove to be an invaluable proxy as attested by Henderson (1996, p. 798), who recently lamented that "there isn't a comprehensive data set covering all states over a period of years to get a real sense of how direct regulatory activity varies across states."

\section{NOTES}

1. See Lester and Lombard (1990) for a good literature review.

2. The ozone monitor data for this study was extracted from the EPA's AIRSData database Monitor Trends Reports (http://www.epa.gov/airsdata/montrnd.htm). The output rankings developed in this paper are for the 48 continental states. This database 
did not contain any monitor trends data for South Dakota so it was excluded from the air quality rankings.

3. We could also develop a weighting scheme for our overall measure along the lines of Blomquist et al. (1988). We avoid doing so because any particular weighting scheme would appear ad hoc. Nevertheless, we provide individual rankings for each media type, allowing the reader to compute rankings based on different weights.

4. Data for ozone exceedances are for the 47 contiguous states (excludes South Dakota since the data are not available) from 1993-1997, and thus form a balanced panel of 235 observations. Data for percentage of rivers and percentage of lakes impaired are biennial (1986-1994) for 48 states; but some data points are randomly missing, thus an unbalanced panel of 209 and 172 observations is available for these regression models.

5. Income and population data are from the State Annual Summary Tables constructed by the Bureau of Economic Analysis. Descriptive statistics for per capita income levels are included in Table 1.

6. We tested for a cubic relationship between income levels and the environmental indicator, but in each case the cubic term was insignificant. These results are available upon request from the authors.

7. Estimated state and time effects are available upon request.

8. For a more formal analysis of emission, or environmental quality convergence, see List (1999).

\section{REFERENCES}

Blomquist, G.C., M.C. Berger, and J.P. Hoehn. 1988. New estimates of quality of life in urban areas, American Economic Review 78 (1), 89-107.

Brown, R., and L. Garner. 1988. Resource guide to state environmental management. Lexington KY: The Council of State Governments.

Brown, R., J. Johnson, and K. Marshall. 1990. Resource guide to state environmental management. Lexington KY: The Council of State Governments.

Duerksen, C. 1983. Environmental Regulation of Industrial Plant Siting. Washington DC: The Conservation Foundation.

Grossman G., and A. Krueger. 1995. Economic growth and the environment, Quarterly Journal of Economics 3: 53-77. U.S. Government Printing Office.

Hausman, J. 1978. Specification tests in econometrics. Econometrica, 46: 1251- 71.

Henderson, V. 1996. Effects of air quality regulation, American Economic Review 86: 789-814.

Holtz-Eakin, D., and T. Selden. 1995. Stoking the fires? $\mathrm{CO}_{2}$ emissions and economic growth, Journal of Public Economics 57: 85-101.

Jaffe, A., S. Peterson, P. Portney, and R. Stavins. 1995. Environmental regulation and the competitiveness of U.S. manufacturing: What does the evidence tell us? Journal of Economic Literature Vol. XXXIII (March): 132-163.

Lester, J. 1986. New federalism and environmental policy, Publius: The Journal of Federalism 16: 149-65.

- 1994. A new federalism? Environmental policy in the States, in Environmental policy in the 1990s, edited by N. Vig and M. Kraft. Washington DC: Congressional Quarterly: 51-69. 
Lester, J., and E. Lombard. 1990. The comparative analysis of state environmental policy, Natural Resources Journal 30: 301-19.

List, J. 1999. Have air pollutant emissions converged amongst U.S. regions? Evidence from unit-root tests, Southern Economic Journal, 66: 144-155.

List, J., and C. Gallet. 1999. The environmental Kuznets curve: Does one size fit all? Ecological Economics, 31: 409-423.

Nathan, R., and F. Doolittle, F. 1983. The consequences of cuts: The effects of the Reagan domestic program on state and local governments. Princeton NJ: Princeton University Press.

Ridley, S. 1987. The state of the states. Washington DC: Fund for Renewable Energy and the Environment.

Tiebout, C. 1956. A pure theory of local government expenditure, Journal of Political Economy 64, 416-24.

U.S. Department of Commerce, Bureau of Economic Analysis. 1929-1994. Washington DC: U.S. Government Printing Office.

U.S. Environmental Protection Agency, Office of Water. 1986-1994. National water quality inventory, Report to the Congress, Washington DC:U.S. Government Printing Office.

Vig, N. and M. Kraft. 1994. Environmental policy in the 1990s. Washington DC: Congressional Quarterly. U.S. Government Printing Office. 